\title{
The Effect Of Colchicine Against Phenotypes And Stomata Pakcoy (Brassica Rapa L) Hydroponically With The NFT (Nutrient Film Technique) System.
}

\author{
Nurdiah Hasana ${ }^{1}$, Ike Apriani ${ }^{1 *}$ \\ ${ }^{1}$ Department of Biology, Faculty of science and technology, Universitas Isalam Negeri Raden Fatah, \\ Palembang \\ *email: ikeapriani_uin@radenfatah.ac.id
}

\section{Article Info}

Key word:

Hidroponic

Brassica rapa $L$.

polyploidy

Mutations

Pakcoy

Article history:

Received: 09/03/2020

Revised: $17 / 04 / 2020$

Accepted: 19/05/2020

\begin{abstract}
Colchicine $\left(\mathrm{C}_{22} \mathrm{H}_{25} \mathrm{O}_{6} \mathrm{~N}\right)$ is a toxic alkaloid compound that causing a polyploidy in the plants, so it produces a robust individuals. The aims of this research are to know the effect of Colchicine against phenotypes and stomata pakcoy (Brassica rapa L) hydroponically with the NFT (Nutrient Film Technique) system. This research used experimental method with a complete random design (CRD), five treatments and five replications. The data were analyzed by using ANAVA with $5 \%$ of credibility. The sample of this research were used pakcoy red arrow F1 nauli with colchicine PO (Control), P1 (250 mg / L), P2 (500 mg / L), $P 3(750 \mathrm{mg} / \mathrm{L}), P 4(1000 \mathrm{mg} / \mathrm{L})$. The result of this study showed that the influence of colchisin against phenotype and the stomata's size of pakcoy plant (Brassica rapa L). The high concentrations of colchicine can caused the size of the phenotype (leaves' number, leaf area, wet weight, dry weight) pakcoy smaller than the control. While the size of the stomata increased, the largest of stomata size was found in the P3 treatment (750 $m g / L)$.
\end{abstract}

Copyright $\odot 2020$ Universitas Islam Negeri Raden Fatah Palembang. All Right Reserved

\section{Introduction}

Colchicine $\left(\mathrm{C}_{22} \mathrm{H}_{25} \mathrm{O}_{6} \mathrm{~N}\right)$ is one of the Antimitotic substances which come from Colchicum Autumnale plants. This substance is a toxic alkaloid that can play a role in inhibiting the process of cells division (mitosis) (Tjay, et al., 2007).

Antimitotic in an organism can cause a polyploidy. The animal who has polyploidy will be sterile meanwhile, if it is on the plants, it will make a more individuals robust (Kadi, 2007). According to Campbell, et al., (2010) polyploidy is a condition where an organism has more than two sets of complete chromosomes in its somatic cells.

Polyploidy in plants can improve the plants' quality through phenotype. Morphologically polyploidy plants will look heavier and bigger than anatomically. Meanwhile, cell size, cell nucleus, diameter of the reed carrier, and stomata are greater than diploid plants (Aili, et al., 2016). So, the success of polyploidy's induction can be observed through changes in phenotype and microscopic observations. 
Polyploidy in Brassica rapa L plants using colchicine with concentrations of $0.01 \%$ and $0.02 \%$ showed different effects on phenotypes (Saputra, et al., 2014). Giving a higher concentration of colchicine are expected to give real effect to the polyploidy in Brassica rapa L.

\section{Materials and Methods}

This research is used an experimental method with a complete random design (CRD) method. This study consisted of 5 treatments ( $0 \mathrm{mg} / \mathrm{L}$ (control), $250 \mathrm{mg} / \mathrm{L}$, $500 \mathrm{mg} / \mathrm{L}, 750 \mathrm{mg} / \mathrm{L}$, and $1000 \mathrm{mg} / \mathrm{L}$ ).

Polyploidy induction is done by soaking Pakcoy seeds into colchicine with each concentration of $0 \mathrm{mg} / \mathrm{L}, 250 \mathrm{mg} / \mathrm{L}$, $500 \mathrm{mg} / \mathrm{L}, 750 \mathrm{mg} / \mathrm{L}$, and $1000 \mathrm{mg} / \mathrm{L}$ for 8 hours. After that, the seeding is carried out for 14 days. Then, the Pakcoy's plant is moved to the NFT hydroponic installation. The success of polyploidy was observed with changes in phenotype (plant height, leaf area, leaves' number, wet weight and dry weight) and stomata size (stomata lenght and widht). The date ware analyzed by analysis of variance (ANOVA) and a further test with different test ranges Duncan (DMRT) at 5\% level.

\section{Results and Discussion}

Based on this research, the results of analysis that is using ANOVA, it is known that giving colchicine can affects several phenotype traits and stomata of the Pakcoy's plant (Brassica rapa L), such as; leaves' number, plant's height, wet weight, dry weight leaf's area, stomata length and width.

Table 1. Observation of leaves' number, plant's height, wet weight and dry weight leaf's area on the 39 th days

\begin{tabular}{cccccc}
\hline Treatments & $\begin{array}{c}\text { plant's } \\
\text { height }\end{array}$ & $\begin{array}{c}\text { leaves' } \\
\text { number }\end{array}$ & $\begin{array}{c}\text { leaf's } \\
\text { area. }\end{array}$ & $\begin{array}{c}\text { wet } \\
\text { weight }\end{array}$ & $\begin{array}{c}\text { dry } \\
\text { weight }\end{array}$ \\
\hline P0 & $26,76 \mathrm{c}$ & $18,9 \mathrm{c}$ & $117,61 \mathrm{~d}$ & $147,55 \mathrm{~d}$ & $7,22 \mathrm{c}$ \\
$\mathrm{P} 1$ & $24,97 \mathrm{c}$ & $16,9 \mathrm{c}$ & $93,14 \mathrm{c}$ & $101,60 \mathrm{c}$ & $4,95 \mathrm{~b}$ \\
$\mathrm{P} 2$ & $18,88 \mathrm{~b}$ & $11,4 \mathrm{~b}$ & $57,36 \mathrm{~b}$ & $38,55 \mathrm{~b}$ & $1,95 \mathrm{a}$ \\
P3 & $13,31 \mathrm{a}$ & $7,8 \mathrm{a}$ & $24,45 \mathrm{a}$ & $11,78 \mathrm{a}$ & $0,49 \mathrm{a}$ \\
P4 & $11,75 \mathrm{a}$ & $6,9 \mathrm{a}$ & $19,71 \mathrm{a}$ & $8,22 \mathrm{a}$ & $0,37 \mathrm{a}$ \\
KK & $14,76 \%$ & $13,64 \%$ & $24,21 \%$ & $27,63 \%$ & $47,84 \%$ \\
\hline
\end{tabular}

Information :The numbers followed by the same letters in the same column are not significantly different in the test ranges Duncan (DMRT) at 5\% level. P0 (0 $\mathrm{mg} / \mathrm{L})$, P1 (250 mg/L), P2 (500 mg/L), D3 (750 mg/L), dan P4 (1000 mg/L)

Table 2. Observation of stomata length and width on the $39^{\text {th }}$ days

\begin{tabular}{ccc}
\hline Treatments & Stomata length $(\boldsymbol{\mu m})$ & Stomata width \\
\hline P0 & $33,4988 \mathrm{a}$ & 24,6509 a \\
P1 & $33,8326 \mathrm{a}$ & $21,3668 \mathrm{a}$ \\
P2 & $41,3622 \mathrm{~b}$ & $30,5438 \mathrm{~b}$ \\
P3 & $77,6238 \mathrm{c}$ & $34,7852 \mathrm{c}$ \\
P4 & $46,7092 \mathrm{~b}$ & $31,0150 \mathrm{bc}$ \\
Kk & $10,09 \%$ & $11,41 \%$ \\
\hline
\end{tabular}

Information :The numbers followed by the same letters in the same column are not significantly different in the test ranges Duncan (DMRT) at 5\% level. P0 (0 mg/L), P1 (250 $\mathrm{mg} / \mathrm{L})$, P2 (500 mg/L), D3 (750 mg/L), dan P4 (1000 mg/L). 

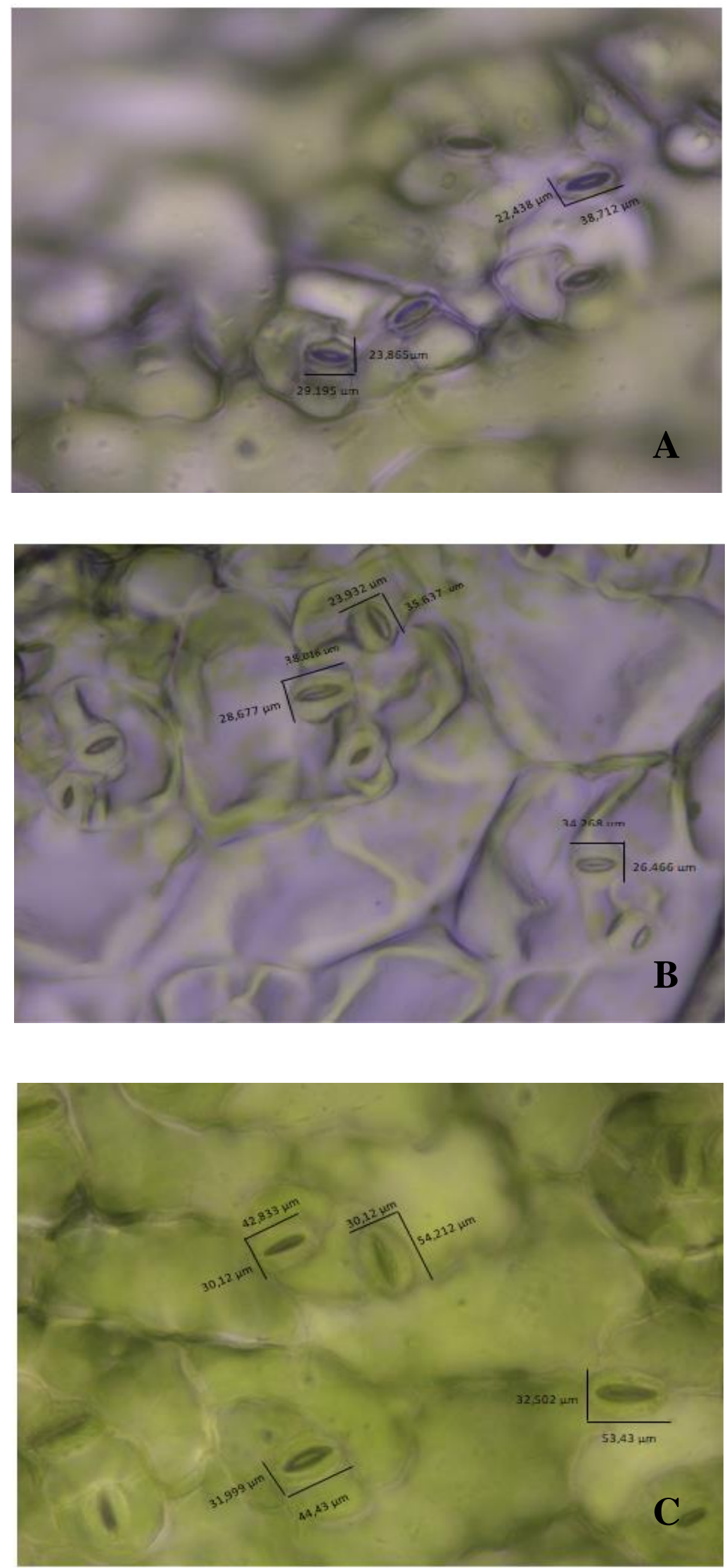

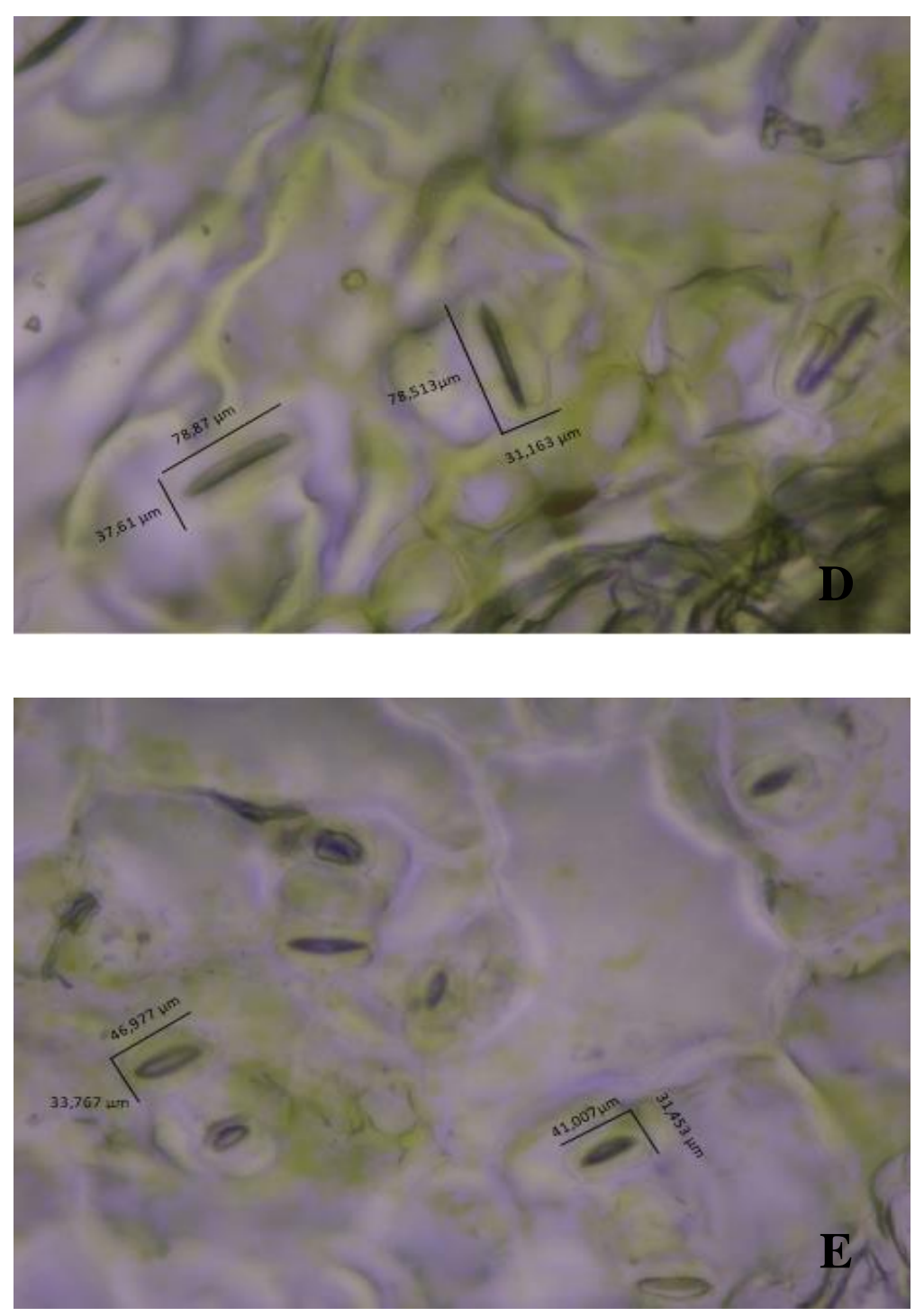

Figure 1. The stomata size of pakcoy's plant with colchicine cncentration a $(0 \mathrm{mg} / \mathrm{L})$, b (250 mg/L), c (500 mg/L), d (750 mg/L), dan e (1000 mg/L) (doc.pribadi, 2019).

\section{Phenotype Observation}

Giving of colchicine has a significant effect on phenotype changes (Table 1). The average of leaves' number, wet weight, dry weight, leaf area and plant height in the control was highest than compared to all treatments. While, the treatment of colchicine in each plant has a different respond. According to Aili, et al., (2016), the differences of response can be caused by the entry of colchicine into plant cells with different times. The colchicine given to plants does not affect the whole plant cell, but only some cells. Colchicine is only active if it is treated when plant cells are actively dividing.

\section{Stomata Observations}

Giving colchicine significantly affect the size of the stomata (Table 2). The highest average stomata size (length and width) was found in the P3 treatment. While, the lowest stomata size was in the control. The increasing size of the Stomata along with the amount of colchicine used indicates that the Pakcoy's plant has undergone polyploidy. 
According to Aili, et al., (2016) plants are through the process of polyploidy have stomata greater than the other dyploidy plants.

The Stomata's size that longer and wider will cause the Stomata to open bigger. This situation causes more $\mathrm{CO} 2$ to enter the leaves. In addition, it can cause an increase in the rate of transpiration that plays a role in maintaining turgidity, maintaining the stability of leaf temperature, and accelerating the rate of transportation of nutrients by the xylem vessels (Lakitan, 2015).

Ideally, a plant that undergoes polyploidy will have a greater phenotype size than a plant that does not undergo polyploidy because its chromosomes have multiplied. But, in this study, the size of the plant is inversely proportional to the concentration of colchicine. The higher the concentration of colchicine used in plant size the smaller this is because its growth is inhibited. According to (Leitch, et al., 2008) with increased genome accumulation, an increase in the need for plant nutrients, especially nitrates and phosphates, will be needed to make nucleic acids and proteins.

\section{Conclusion}

The administration of colchicine has a significant effect on changes in pakcoy phenotypes such as plant height, leaf area, wet weight, dry weight and number of leaves of pakcoy plants, and Giving colchicine affects the length and width of the pakcoy plant stomata.

\section{Acknowledgment}

Thanks to the State Islamic University (UIN) Raden Fatah Palembang for providing research funding, State University Operational Assistance (BOPTN) in 2019.

\section{References}

Aili, E. N., Respatijarti, \& Sugiharto, A. N. (2016). Pengaruh Pemberian Kolkisin
Terhadap Penampilan Fenotip Galur Inbrida Jagung Pakan (Zea Mays L.) Pada Fase Pertumbuhan Vegetatif. 4(5), 370-377.

Campbell, N. A., \& Reece, J. B. (2010). Biologi. Jakarta: Erlangga.

Kadi, A. (2007). Manipulasi Poliploidi Untuk Memperoleh Jenis Baru Yang Unggul. Oceana, Xxxii(4): 1-11

Lakitan, B. (2015). Dasar-Dasar Fisiologi Tumbuhan. Depok: PT Rajagrafindo Persada.

Leitch, A. R., \& Leitch, I. (2008). Genomic Plasticity and the diversity of polyploidi plants. 320: 481-483.

Saputra, E. H., Soetopo, L., \& Respatijarti. (2014). Aplikasi Kolkhisin Terhadap Pertumbuhan Dan Produksi Benih Sawi ((Brassica Rapa). Produksi Tanaman, 1(6), 501-505.

Tjay, T. H., \& Rahardja, K. (2007). ObatObat Penting. Jakarta: Pt Elex Media Komputindo. 